\title{
Influenza infection during pregnancy
}

\author{
Rauf Melekoğlu', Uğur Keskin², Ebru Tarım³, Cihat Şen ${ }^{4}$ \\ ${ }^{1}$ Department of Obstetrics and Gynecology, Faculty of Medicine, İnönï University, Malatya, Turkey \\ ${ }^{2}$ Gynecology and Obstetrics Clinic, Gülhane Training and Research Hospital, Ankara, Turkey \\ ${ }^{3}$ Gynecologist and Obstetrician, Adana, Turkey \\ ${ }^{4}$ Department of Gynecology and Obstetrics, Cerrahpaşa Faculty of Medicine, Istanbul University, Istanbul, Turkey
}

\begin{abstract}
Influenza is the acute viral infection of respiratory system which is seen commonly and usually self-limiting. In some specific cases such as pregnancy, the complications of the disease tend to be seen more common compared to the general population. During influenza season, the admission to the hospital, hospitalization requirement and intensive care need due to acute respiratory distress in pregnant women because of influenza infection is significantly higher than the women who are not pregnant. Seasonally, the first cases with influenza infection are reported in October, with an increase in the reports during January and February, and the cases are reported until May. During the period between October and May, known as the influenza season, inactive influenza vaccination is recommended for pregnant women. Inactive influenza vaccination can be done at any period of pregnancy. Although live attenuated influenza vaccines can be used during postpartum period, it should not be used during pregnancy. The diagnosis of influenza infection is usually established clinically. Empiric treatment is recommended for pregnant women in case of clinical suspicion, without waiting for the results of diagnostic tests particularly in pandemic conditions. The pregnant women with hospitalization indication, who are suspected or confirmed for influenza infection, should be hospitalized and appropriate antiretroviral treatment should be initiated as soon as possible without waiting for the results of diagnostic tests. During pregnancy, the use of neuroaminidase inhibitor antiviral medications is indicated for the treatment and prophylaxis after influenza exposure for patients who have suspected or confirmed influenza infection. Oseltamivir is an outstanding neuroaminidase inhibitor to use in the treatment and prophylaxis of influenza infection during pregnancy as the resistance rate of influenza strains is low, its systemic absorption is well and clinical experience regarding this medication is high.
\end{abstract}

Keywords: Influenza, influenza vaccine, oseltamivir, pregnancy.

\section{Introduction}

Influenza is the acute viral infection of respiratory system which is seen commonly and usually self-limiting. The transmission rate of influenza viruses is quite high

\section{Özet: Gebelikte influenza enfeksiyonu}

İnfluenza virüs enfeksiyonu skk görülen ve genellikle kendini sınırlayan solunum sisteminin akut viral enfeksiyonudur. Gebelik gibi bazı özel durumlarda genel topluma oranla hastalı̆̆ın komplikasyonları daha ssk görülme eğilimindedir. İnfluenza sezonu boyunca gebe kadınlarda influenza enfeksiyonu nedeniyle hastaneye başvuru sayısı, hastaneye yatıs ihtiyacı ve akut respiratuvar distres nedenli yoğun bakım ihtiyacı gebe olmayan kadınlara oranla anlamlı oranda yüksektir. İnfluenza enfeksiyonunda mevsimsel olarak ilk olgular genelde Ekim ayı gibi bildirilmeye başlanmakta, Ocak-Şubat aylarında olgu sayılarında ciddi artış olmakta ve Mayıs ayına kadar olgular bildirilmeye devam etmektedir. İnfluenza sezonu olarak bilinen Ekim-Mayıs ayları arasında gebe olan kadınların inaktive influenza aşısı ile aşılanmaları önerilmektedir. İnaktive influenza aşısı gebeliğin herhangi bir zamanında uygulanabilir. Canlı, atenüe influenza aşıları postpartum dönemde kullanılabilse de gebelik döneminde kullanılmamalıdır. İnfluenza enfeksiyonu tanısı daha çok klinik olarak konur. Özellikle pandemi durumlarında tanısal testlerin sonucu beklenmeden klinik şüphe durumunda gebelere ampirik tedavi önerilmektedir. İnfluenza enfeksiyonu şüphesi olan veya influenza enfeksiyonu olduğu doğrulanmış, hastaneye yatış endikasyonu olan gebeler hastaneye yatırılmalı ve uygun antiretroviral tedavi, tanısal testlerin sonuçları beklenmeden hızlıca başlanmalıdır. Gebelik sırasında nöraminidaz inhibitörü antiviral ilaçların kullanımı, şüpheli veya kanıtlanmış influenza enfeksiyonu bulunan hastaların tedavisi ve influenza maruziyetinden sonra profilaksisi için endikedir. Oseltamivir, influenza suşlarında direnç görülme oranının düşük olması, sistemik emiliminin iyi olması ve bu ilaçla ilgili klinik deneyimin yüksek olması nedeniyle gebelikte influenza enfeksiyonu tedavisi ve profilaksisinde kullanılması önerilen seçkin bir nöraminidaz inhibitörüdür.

Anahtar sözcükler: Gebelik, influenza, influenza aşısı, oseltamivir.

and it may affect people of all ages. In some specific cases such as pregnancy, the complications of the disease tend to be seen more common compared to the general population. ${ }^{[1]}$ Although it seems that the risk
Correspondence: Rauf Melekoğlu, MD. Department of Obstetrics and Gynecology, Faculty of Medicine, İnönü University, Malatya, Turkey. e-mail: rmelekoglu@gmail.com Received: November 15, 2017; Kabul tarihi: December 12, 2017

Please cite this article as: Melekoğlu R, Keskin U, Tarım E, Şen C. Influenza infection during pregnancy. Perinatal Journal 2017;25(3):139-144.
Available online at: www.perinataljournal.com/20170253005 doi: $10.2399 / \mathrm{prn} .17 .0253005$ QR (Quick Response) Code: 
for influenza infection is limited with the third trimester of pregnancy and the first 4 weeks of postpartum period, the evidence level of the data on this matter is not high. ${ }^{[2]}$ The reasons for severe progress of influenza infections during pregnancy are associated with the physiological changes of pregnancy such as the increased heart rate and oxygen consumption during pregnancy, reduced pulmonary capacity due to the elevated diaphragm and decreased cellular immunity as a result of the shift from Th1 to Th2 with the effects of estradiol and progesterone. ${ }^{[3]}$ During influenza season, the admission to the hospital, hospitalization need, hospitalization duration and the need for hospitalization in the intensive care unit due to acute respiratory distress in pregnant women because of influenza infection is significantly higher than the women who are not pregnant. ${ }^{[4]}$ It was reported that pregnant women admit to hospitals for influenza infection 6.8 times higher (relative risk: 3.5-25.3) and their intensive care requirement is 6.5 times higher than normal population. $^{[5,6]}$

\section{Epidemiology}

Seasonally, the first cases with influenza infection are reported in October, with an increase in the reports during January and February, and the cases are reported until May. Although high mortality rates were reported associated with the pandemic seasonal influenza infections in the years 1918-1919 and 1957-1958, high mortality rates seen in 2009 H1N1 pandemic which is never seen before attracted the attention. ${ }^{[7]}$ While the influenza virus infections were accounted for $5 \%$ of all deaths in 2009 in the USA, $12 \%$ of maternal deaths were associated with H1N1 pandemic. While maternal mortality rate was $2.9 / \mathrm{mil}-$ lion in seasonal influenza infections, it was reported 20/million in 2009 pandemic. ${ }^{[5]}$ Since 2009, H1N1associated maternal deaths which can be prevented have still been reported all over the world. ${ }^{[8]}$ According to the data of Turkish Ministry of Health, 272 patients died during H1N1 pandemic in 2009 in Turkey. According to the report of Pandemic Coordination Unit of Turkish Ministry of Health dated January 5, $2010,6.1 \%$ of the patients who died of Influenza A H1N1-2009 infection were pregnant and puerperal women. ${ }^{[9]}$ These data clearly show the importance of vaccination against influenza during pregnancy and postpartum periods.

\section{Pathogenesis}

Influenza virus is a RNA virus from Orthomyxoviridae family and it has three antigenic types. These are Type A, Type B and Type C. Types A and B are responsible for many clinical diseases. A and B are the types causing important clinical issues and seasonal epidemics while Type $\mathrm{C}$ is the type mostly causing seasonal mild upper respiratory tract diseases. Influenza $\mathrm{A}$ is categorized according to two glycoproteins it carries on its surface. These are hemagglutinin (HA) and neuroaminidase (NA) antigens and it is known today that HA may have 16 different sub-types and NA may have 9 different subtypes, and they may establish a great number of combinations. Influenza B has no sub-type. ${ }^{[10]}$

\section{Diagnosis and Clinical Progress}

The diagnosis is established with the presence of unexplained fever exceeding $38^{\circ} \mathrm{C}$ or fever together with at least one of the complaints of common body pain, sore throat, headache, nasal flow, cough, respiratory distress, vomiting and diarrhea. The final diagnosis is confirmed by the detection of virus by real-time polymerase chain reaction (PCR) or virus culture in one of the reference laboratories. ${ }^{[1]}$ Empiric treatment is recommended for pregnant women in case of clinical suspicion, without waiting for the results of diagnostic tests in pandemic conditions. There are many diagnostic tests providing rapid results. Most of them are qualitative tests and they provide positive or negative result. In these tests, specificity is between $85 \%$ and $100 \%$ while sensitivity is between $45 \%$ and $62 \%$. Therefore, even though the result of rapid diagnostic test is negative, clinically suspicious cases should also be treated. ${ }^{[12]}$

The incubation period of influenza infection is 1-4 days. Most of the cases know who transmits the disease. This is either a family member or a colleague. The most common symptoms are cough, fever (rarely above $40^{\circ} \mathrm{C}$, $<2 \%$ ), myalgia, nasal flow, sore throat and headache, and tachycardia. Many symptoms recover within a week; however, cough and malaise may continue up to two weeks. ${ }^{[13]}$

\section{Maternal Effects}

Influenza infection has a more severe clinical progress in pregnant women compared to the general population. ${ }^{[14]}$ The risk tends to increase especially during third trimester and within first 4 weeks of postpartum period. ${ }^{[2]}$ The clinical progress during pregnancy may vary 
depending on the immunization against influenza. The most common and sever complication of influenza infection during pregnancy is pneumonia and it can develop due to primary viral or secondary bacterial reasons. Since both viral and bacterial pneumonias developing during pregnancy and early postpartum periods may have an adverse progress, early diagnosis should be established and empiric antiviral treatment should be initiated as soon as possible if the influenza infection is symptomatic.

\section{Fetal Effects}

Although the transplacental transmission of influenza virus is rare, this transmission was shown in the case with fatal avian influenza (H5N1) infection. ${ }^{[15,16]}$ It should not be ignored that influenza infection may have fetal effects even in cases where there is no transplacental transmission. Based on some observational studies and case reports, it was argued that influenza infection is associated with congenital anomalies (cleft lip, neural tube defect, hydrocephaly and congenital heart disease), spontaneous abortion, preterm labor, low birth weight and fetal death. ${ }^{[17-19]}$ Besides, it is suggested that hyperthermia developing as a result of infection is a risk factor for the development of fetal anomalies, and the use of antipyretics would reduce this risk. ${ }^{[20]}$

The rate and severity of fetal complications is in proportion to the severity of maternal disease. In ambulatory patients, gestational outcomes are similar to the general population. However, the rates of preterm labor, birth weight small for gestational age (SGA) and fetal death increase in hospitalized patients. ${ }^{[1]}$ In a study showing the UK national data after 2009 influenza A H1N1 pandemic, perinatal mortality was found 39/1000 (7/1000 in noninfected women), and there were 4-fold increased preterm labor risk, newborn intense care need $(\mathrm{p}<0.001)$ and secondary pneumonia $(\mathrm{p}<0.001){ }^{[21]}$ Another study reported that there was no difference between pregnant women with $\mathrm{H} 1 \mathrm{~N} 1$ infection and the control group in terms of perinatal outcomes. However, the patients with severe infection were compared with the control group in the sub-group analysis, and the risk of group with severe infection was found higher in terms of SGA $(18.8 \%$ vs. $7.4 \%)$ and preterm labor (25\% vs. $11.6 \%){ }^{[22]}$

\section{Vaccination and Prophylaxis}

The Centers for Disease Control and Prevention (CDC) recommends to vaccine $\geq 6$-month pediatric group and all adult population including pregnant women, all who have no contraindication, annually against influenza. ${ }^{[19]}$ American College of Obstetricians and Gynecologists Influenza vaccine in pregnancy is categorized as Category-B and $\mathrm{C}$ which there is no any evidence to cause any harm for the fetus while there is limited data about that its use is safe in first trimester in pregnancy. But $\mathrm{CDC}$ is recommending influenza vaccination before or during any influenza season. ${ }^{[19]}$ American College of Obstetricians and Gynecologists (ACOG) also recommends vaccination for pregnant women regardless of their weeks of gestation. ${ }^{[7]}$ Vaccinating pregnant women, as soon as inactive influenza vaccine is available, between October and May which is known is influenza season is important particularly. Inactive influenza vaccination can be done at any period of pregnancy. Besides, October is considered as the most appropriate time for vaccination. When the time of vaccination delayed to November, a decrease is seen in the activity of vaccine. ${ }^{[12]}$ Post-immunization protective immune response is provided within 14 days. It was reported that no increase in the fetal anomaly risk was observed and stillbirth risk decreased in pregnant women who were vaccinated with first trimester trivalent (triple vaccine) inactive influenza vaccine. ${ }^{[23]}$ Independent from the week of gestation for vaccination, it was reported that there was a decreased risk for stillbirth, neonatal death and preterm labor by vaccination. Although live attenuated influenza vaccines can be used during postpartum period, it should not be used during pregnancy. Two types of influenza vaccine are available, which are quadrivalent (two vaccines containing influen$\mathrm{za} A$ virus and two vaccines containing influenza $B$ virus) and trivalent (two vaccines containing influenza $\mathrm{A}$ virus and one vaccine containing influenza $B$ virus). ${ }^{[2]}$ The Centers for Disease Control and Prevention did not recommend any specific vaccine among these two types of influenza vaccines as there are no studies comparing the impacts of these two vaccine types on wider populations, and reported that any of the vaccine types can be used for immunization. Although the rates of vaccination against influenza by pregnant women were very low previously, this rate reached up to $54 \%$ in the USA with the influences of national studies after 2009 pandemic. ${ }^{[25]}$ It has been showed that the rates of influenza vaccination are higher when healthcare professionals, especially those providing gestational healthcare, inform and provide recommendation about vaccination. Therefore, it is important to inform about the significance of influenza vaccination by healthcare professionals. 
In their Cochrane review, Demicheli et al. showed that 2009/2010 monovalent pandemic H1N1 vaccination reduced the rates of influenza-like diseases by $89 \%$ in pregnant women, and seasonal inactive vaccine reduced the rates of influenza-like diseases by $24 \% .{ }^{[2]}$ Another review conducted in 2015 showed that influenza vaccination during pregnancy was associated with the decrease in stillbirth rates although it did not have any impact on low rates. ${ }^{[2]}$ On the other hand, it is known that influenza vaccination during pregnancy protects the newborn for a long time after birth. Antenatal immunization stimulates the production of anti-influenza-specific serum immunoglobulin $\mathrm{G}$ (IgG) and this immunoglobulin passes through placenta during fetal period and through breast milk during newborn period. ${ }^{[28,29]}$ Therefore, maternal immunization during antenatal period is an effective strategy to reduce morbidity and mortality associated with influenza in newborns, and it is also important for the protection against the infection in this group, which has no chance for vaccination in their first 6 months of life and under risk in terms of severe influenza infection. ${ }^{[30]}$

The contraindications of the vaccine are similar to those of all other vaccines. It should be avoided in case of allergy and high fever against the substances of vaccine. Although many pregnant women have concerns about the adverse effects on fetus, there are many studies showing that influenza vaccine does not increase the complication risk in pregnant women and fetuses. ${ }^{[31,32]}$ In addition, like in all other vaccines, adverse effects such as Guillain-Barre syndrome were also reported very rarely in influenza vaccine. ${ }^{[33]}$ However, no specific risk was shown on pregnant women, fetuses and newborns.

Taking standard precautions, which is the basic factor for the prevention of all infections as well as vaccination, is also significant to prevent influenza infection. Among these precautions are hand hygiene (washing hands with water and soap) and respiratory hygiene (keeping mouth closed when coughing, preventing contact with respiratory secretions etc.). ${ }^{[34]}$

\section{Treatment}

The pregnant women with hospitalization indication, who are suspected or confirmed for influenza infection, should be hospitalized in a special room and appropriate antiretroviral treatment should be initiated as soon as possible without waiting for the results of diagnostic tests. Cases with severe or persistent symptom(s), those espe- cially with respiratory symptom(s) and patients who do not exhibit any recovery within 7 days despite the standard precautions and antiviral treatment are the patient group which should be hospitalized and monitored. Ambulatory patients should be monitored properly in terms of respiratory findings. Antiretroviral treatment should be initiated promptly for patients who are suspected for influenza during pregnancy and postpartum periods. There are two groups of agents for antiviral treatment. M2 inhibitors, amantadine and rimantadine, as the agents in the first group, are only used for the treatment and prophylaxis of influenza $\mathrm{A}$. These agents have not been recommended in the primary treatment since 2005-2006 influenza season due to high resistance. Neuroaminidase inhibitors such as oseltamivir, peramivir and zanamivir, as the agents in the second group, are effective for both influenza A and influenza B. This group has been recommended in the primary treatment since $2006 .{ }^{[35]}$

In the past, both CDC and ACOG were cautious for antiviral treatment in pregnant women due to the lack of insufficient data. However, after 2009 season, CDC recommends antiviral treatment for both prophylaxis and treatment. ${ }^{[35]}$ Most of the influenza viruses are sensitive against neuroaminidase inhibitors such as oseltamivir, peramivir and zanamivir. Oseltamivir is an outstanding neuroaminidase inhibitor as the resistance rate of influenza strains is low, its systemic absorption is well and clinical experience regarding this medication is high. As in non-pregnant women, the dose is $75 \mathrm{mg}$ twice per day for 5 days. During the prophylaxis, $75 \mathrm{mg}$ per day for 10 days is recommended. In severe influenza infections, it can be used in higher doses for a longer period. It also can be used during lactation period. It reaches to a specific concentration in breast milk; however, it is below the treatment dose for newborn. Zanamivir is an inhaler agent and can be used by pregnant women. It is important to reduce the fever since hyperthermia during first trimester increases congenital malformation risk such as neural tube defects and is a risk factor during the labor in terms of neonatal encephalopathy, seizure, cerebral palsy and neonatal death, and the use of acetaminophen is recommended since the side effect profile as an antipyretic agent is lower than other antipyretic agents. ${ }^{[3-40]}$ In cases with severe progress, the treatment should be decided by virological PCR test. In cases which cannot be administered oseltamivir in particular, intravenous peramivir and inhaler zanamivir can be administered. Although effective results are obtained by initiating the treatment 
particularly within the first two days when symptoms are observed, treatment should be recommended without considering the duration of symptoms as recovery is observed in the progress of the disease in patients whose treatments are initiated in later phases.

There is no guideline published for fetal monitorization during and after maternal influenza infection in pregnancy. Fetal follow-up frequency and type should be individualized according to each patient and should be carried out in accordance with the decision of physician.

\section{Conclusion}

Influenza infection is a common viral respiratory tract disease affecting a significant part of the population during influenza season. The pregnancy prominently increases the risks associated with influenza infection and severe disease and death are seen more frequently in pregnant women compared to the general population. Influenza diagnosis should be established clinically without waiting for the results of diagnostic tests. Influenza vaccination is an effective method to prevent influenza infection. All women who are pregnant or about to deliver during influenza season should be vaccinated by trivalent or quadrivalent influenza vaccine independent from the trimester of pregnancy. While vaccination during pregnancy is a safe and cost-effective method, it also provides neonatal protection against influenza due to the partial transplacental transfer of protective antibodies. During pregnancy, the use of neuroaminidase inhibitor antiviral medications is indicated for the treatment and prophylaxis after influenza exposure for patients who have suspected or confirmed influenza infection.

Conflicts of Interest: No conflicts declared.

\section{References}

1. Meijer WJ, van Noortwijk AG, Bruinse HW, Wensing AM. Influenza virus infection in pregnancy: a review. Acta Obstet Gynecol Scand 2015:94:797-819.

2. Mertz D, Kim TH, Johnstone J, Lam PP, Science M, Kuster SP, et al. Populations at risk for severe or complicated influenza illness: systematic review and meta-analysis. BMJ 20134;347: f5061.

3. Phadke VK, Omer SB. Maternal vaccination for the prevention of influenza: current status and hopes for the future. Expert Rev Vaccines 2016;15:1255-80.

4. Mertz D, Geraci J, Winkup J, Gessner BD, Ortiz JR, Loeb M. Pregnancy as a risk factor for severe outcomes from influenza virus infection: a systematic review and meta-analysis of observational studies. Vaccine 2017;35:521-8.
5. Van Kerkhove MD, Vandemaele KA, Shinde V, et al.; WHO Working Group for Risk Factors for Severe H1N1pdm Infection. Risk factors for severe outcomes following 2009 influenza A (H1N1) infection: a global pooled analysis. PLoS Med 2011;8:e1001053.

6. Kelly H, Mercer G, Cheng A. Quantifying the risk of pandemic influenza in pregnancy and indigenous people in Australia in 2009. Euro Surveill 2009;14:pii:19441.

7. Committee on Obstetric Practice and Immunization Expert Work Group; Centers for Disease Control and Prevention's Advisory Committee on Immunization, United States; American College of Obstetricians and Gynecologists. Committee opinion no. 608: influenza vaccination during pregnancy. Obstet Gynecol 2014;124:648-51.

8. Siston AM, Rasmussen SA, Honein MA, Fry AM, Seib K, Callaghan WM, et al.; Pandemic H1N1 Influenza in Pregnancy Working Group. Pandemic 2009 influenza A (H1N1) virus illness among pregnant women in the United States. JAMA 2010; 303:1517-25.

9. Atalay B, Atalay S, Saydam BK. Influenza (flu) A H1N1-2009: pregnancy and postpartum period. e-Journal of New World Sciences Academy Life Sciences 2010;5:7-12.

10. Beigi RH. Influenza during pregnancy: a cause of serious infection in obstetrics. Clin Obstet Gynecol 2012;55:914-26.

11. Köşüş N, Köşüş A, Simavlı SA, Duran Erdolu M, Öztürk Turhan N. H1N1 influenza: pregnancy and lactation: review. Turkiye Klinikleri Journal of Gynecology \& Obstetrics 2009; 19:354-60.

12. Duryea EL, Sheffield JS. Influenza: threat to maternal health. Obstet Gynecol Clin North Am 2015;42:355-62.

13. Tarım E, Özdemir H. Parvovirus and influenza infections in pregnancy. Turkiye Klinikleri Journal of Gynecology \& Obstetrics - Special Topics 2016;9:11-6.

14. Mosby LG, Rasmussen SA, Jamieson DJ. 2009 pandemic influenza A (H1N1) in pregnancy: a systematic review of the literature. Am J Obstet Gynecol 2011;205:10-8.

15. Irving WL, James DK, Stephenson T, Laing P, Jameson C, Oxford JS, et al. Influenza virus infection in the second and third trimesters of pregnancy: a clinical and seroepidemiological study. BJOG 2000;107:1282-9.

16. Gu J, Xie Z, Gao Z, Liu J, Korteweg C, Ye J, et al. H5N1 infection of the respiratory tract and beyond: a molecular pathology study. Lancet 2007;370:1137-45.

17. Luteijn JM, Brown MJ, Dolk H. Influenza and congenital anomalies: a systematic review and meta-analysis. Hum Reprod 2014;29:809-23.

18. Bloom-Feshbach K, Simonsen L, Viboud C, Mølbak K, Miller MA, Gottfredsson M, et al. Natality decline and miscarriages associated with the 1918 influenza pandemic: the Scandinavian and United States experiences. J Infect Dis 2011;204:1157-64.

19. Centers for Disease Control and Prevention (CDC). Prevention and control of seasonal influenza with vaccines. Recommendations of the Advisory Committee on Immunization Practices - United States, 2013-2014. MMWR Recomm Rep 2013;62(RR-07):1-43. 
20. Moretti ME, Bar-Oz B, Fried S, Koren G. Maternal hyperthermia and the risk for neural tube defects in offspring: systematic review and meta-analysis. Epidemiology 2005:16:216-9.

21. Pierce M, Kurinczuk JJ, Spark P, Brocklehurst P, Knight M; UKOSS. Perinatal outcomes after maternal 2009/H1N1 infection: national cohort study. BMJ 2011; 342:d3214.

22. Naresh A, Fisher BM, Hoppe KK, Catov J, Xu J, Hart J, et al. A multicenter cohort study of pregnancy outcomes among women with laboratory-confirmed H1N1 influenza. J Perinatol 2013;33:939-43.

23. Sheffield JS, Greer LG, Rogers VL, Roberts SW, Lytle H, McIntire DD, et al. Effect of influenza vaccination in the first trimester of pregnancy. Obstet Gynecol 2012;120:532-7.

24. Swamy GK, Heine RP. Vaccinations for pregnant women. Obstet Gynecol 2015;125:212-26.

25. Ding H, Black CL, Ball S, Fink RV, Williams WW, Fiebelkorn $\mathrm{AP}$, et al. Influenza vaccination coverage among pregnant women - United States, 2016-17 influenza season. MMWR Morb Mortal Wkly Rep 2017;66:1016-22.

26. Demicheli V, Jefferson T, Al-Ansary LA, Ferroni E, Rivetti A, Di Pietrantonj C. Vaccines for preventing influenza in healthy adults. Cochrane Database Syst Rev 2014;(3):CD001269.

27. Bratton KN, Wardle MT, Orenstein WA, Omer SB. Maternal influenza immunization and birth outcomes of stillbirth and spontaneous abortion: a systematic review and meta-analysis. Clin Infect Dis 2015;60:e11-9.

28. Wutzler P, Schmidt-Ott R, Hoyer H, Sauerbrei A. Prevalence of influenza A and B antibodies in pregnant women and their offspring. J Clin Virol 2009;46:161-4.

29. Schlaudecker EP, Steinhoff MC, Omer SB, McNeal MM, Roy $\mathrm{E}$, Arifeen SE, et al. IgA and neutralizing antibodies to influenza a virus in human milk: a randomized trial of antenatal influenza immunization. PLoS One 2013;8:e70867.

30. Halasa NB, Gerber MA, Chen Q, Wright PF, Edwards KM. Safety and immunogenicity of trivalent inactivated influenza vaccine in infants. J Infect Dis 2008;197:1448-54.

31. Kharbanda EO, Vazquez-Benitez G, Romitti PA, Naleway AL, Cheetham TC, Lipkind HS, et al.; Vaccine Safety Datalink.
First trimester influenza vaccination and risks for major structural birth defects in offspring. J Pediatr 2017;187(Suppl C): 234-9.e4.

32. McMillan M, Porritt K, Kralik D, Costi L, Marshall H. Influenza vaccination during pregnancy: a systematic review of fetal death, spontaneous abortion, and congenital malformation safety outcomes. Vaccine 2015;33:2108-17.

33. De Wals P, Deceuninck G, Toth E, Boulianne N, Brunet D, Boucher RM, et al. Risk of Guillain-Barré syndrome following H1N1 influenza vaccination in Quebec. JAMA 2012;308:17581.

34. Garner JS. Guideline for isolation precautions in hospitals. The Hospital Infection Control Practices Advisory Committee. Infect Control Hosp Epidemiol 1996;17:53-80.

35. Greer LG, Sheffield JS, Rogers VL, Roberts SW, McIntire DD, Wendel GD Jr. Maternal and neonatal outcomes after antepartum treatment of influenza with antiviral medications. Obstet Gynecol 2010;115:711-6.

36. Fiore AE, Fry A, Shay D, Gubareva L, Bresee JS, Uyeki TM; Centers for Disease Control and Prevention (CDC). Antiviral agents for the treatment and chemoprophylaxis of influenza recommendations of the Advisory Committee on Immunization Practices (ACIP). MMWR Recomm Rep 2011;60:1-24.

37. Louie JK, Jamieson DJ, Rasmussen SA. 2009 pandemic influenza A (H1N1) virus infection in postpartum women in California. Am J Obstet Gynecol 2011;204:144.e1-6.

38. Graner S, Svensson T, Beau AB, Damase-Michel C, Engeland A, Furu K, et al. Neuraminidase inhibitors during pregnancy and risk of adverse neonatal outcomes and congenital malformations: population based European register study. BMJ 2017; 356:j629.

39. Hsu J, Santesso N, Mustafa R, Brozek J, Chen YL, Hopkins JP, et al. Antivirals for treatment of influenza: a systematic review and meta-analysis of observational studies. Ann Intern Med 2012;156:512-24.

40. Edwards MJ. Review: hyperthermia and fever during pregnancy. Birth Defects Res A Clin Mol Teratol 2006;76:507-16. 